\title{
Emergence of several Triticeae range grasses influenced by depth of seed placement
}

\author{
T. LAWRENCE, C.D. RATZLAFF, AND P.G. JEFFERSON
}

\section{Abstract}

Seed of 8 Triticere species was planted in petri dishes (depth $=0$ ) and $2,4,6$, and $8 \mathrm{~cm}$ deep in soil in the greenhouse. Total emergence at 6 weeks after planting declined significantly with increased depth and the species by depth interaction was significant $(P<0.001)$. Dahurian wildrye (Elymus dahuricus Turcz. ex Griseb.) and tetraploid Russian wildrye (Psathyrostachys juncea [Fisch.] Nevski) exhibited similar emergence from deep seedings and were superior to all other species except Altai wild ryegrass (Leymus angustus [Trin.] Pilger). The better emergence of the tetraploid Russian wildrye entry compared to diploid cultivar suggests that the establishment of the tetraploid cultivar will be less affected by poor seed depth control. Newly released cultivars of Dahurian wildrye will be less affected by variable seed depth than several of the species currently recommended for seeding rangelands.

Key Words: Dahurian wild ryegrass, Altai wild ryegrass, Russian wild ryegrass, slender wheatgrass, intermediate wheatgrass, crested wheatgrass, Nuttall's alkali grass

Variable seed depth is a major cause of establishment failure on semiarid rangelands and may result from inadequate depth control of seeding equipment (Lawrence and Dyck 1990), rough microtopography, or poor seedbed preparation. Emergence of seedlings from seed depths greater than $2.5 \mathrm{~cm}$ would be an advantageous trait in dryland grasses. 'Tetracan', a newly released tetraploid ( $2 \mathrm{~N}$ $=4 \mathrm{X}=28$ ) Russian wildrye (Psathyrostachys juncea [Fisch.] Nevski) cultivar has larger seed mass and greater emergence from $4.5 \mathrm{~cm}$ depth of seeding than diploid cultivars (Lawrence et al. 1990b). The emergence of Tetracan from deeper seeding has not been documented. Dahurian wildrye (Elymus dahuricuz Turcx. ex Griseb.) is a recently introduced species with high establishment year forage yield that has been identified for seeding in mixtures with slower establishing species in semiarid locations in Western Canada (Lawrence and Ratzlaff 1985, Lawrence et al. 1990a). The present study was conducted to determine the response of these new cultivars to increasing seed depth relative to other grass species.

Authors are research scientist (retired), grass breeding technician, and research scientist, Research Station, Research Branch, Agriculture Canada, Box 1030, Swift Current Saskatchewan S9H 3X2, respectively.

Manuscript accepted 28 May 1990.

\section{Methods}

The experiment was conducted over a 6-week period in a greenhouse with temperature maintained at approximately $25^{\circ} \mathrm{C}$ in a 16-hour photoperiod with surface applied water as required. One hundred viable seeds in single rows constituted individual plots. The experimental design and treatments were as follows:

Design 4 replicate split plot.

Main Plots-8 grasses: Altai wildrye (Leymus angustus [Trin.] Pilger) 'Prairieland'; Dahurian wildrye 'James'; Russian wildryediploid 'Swift'; Russian wildrye-tetraploid 'Tetracan'; slender wheatgrass (Elymus trachycaulus [Link] Gould ex Shinners) 'Revenue'; intermediate wheatgrass (Thinopyrum intermedium (Host) Barkworth and D.R. Dewey subsp. intermedium) 'Clarke'; crested wheatgrass (Agropyron desertorum [Fisch. ex Link] Schultes) 'Summit'; and Nutall's alkali grass (Puccinellia tenuiflora Schribn. \& Merr.) Sc 186169 (an accession from People's Republic of China via S. Smoliak, Lethbridge Research Station).

Split-plots-Five seeding depths: 0 (in petri dishes), 2, 4, 6, and 8 cm, using methods outlined by Lawrence (1979).

Soil Mix-loam: with $41.5 \%$ sand, $21.6 \%$ clay and $36.9 \%$ silt.

Data Analysis-Emergence (\%) was determined 6 weeks after planting. Emergence at all depths was adjusted to correct 0 depth data to $100 \%$. Analysis of variance based on the split plot model and regression of entry means on depth were computed with SAS General Linear Models procedure.

\section{Results and Discussion}

The final emergence of the 8 grass species decreased with increasing depth of seeding (Table 1). The species, depth, and species by depth interaction effects were all highly significant $(P<0.001)$. First or second order regression equations with depth as the independent variable accounted for more than $90 \%$ of the variability in emergence for all species. Altai wildrye was least affected by deep seed placement as previously reported (Kilcher and Lawrence 1970). The tetraploid Russian wildrye had greater emergence than the diploid Russian wildrye. This conclusion indicates that seedling establishment of the new cultivar Tetracan should be less variable than has been observed for previous diploid cultivars. Dahurian wildrye exhibited excellent emergence to $6 \mathrm{~cm}$ depth and was less affected by seed depth than crested wheatgrass or diploid

Table 1. Mean emergence (\%) of 8 grasses $(n=4), 6$ weeks after planting at 5 depths and regression equation of mean emergence on depth.

\begin{tabular}{|c|c|c|c|c|c|c|c|c|}
\hline \multirow[b]{2}{*}{ Grass } & \multicolumn{5}{|c|}{ Depth $(\mathrm{cm})$} & \multirow[b]{2}{*}{ Regression } & \multirow[b]{2}{*}{$R^{2}$} & \multirow[b]{2}{*}{ SEE $^{1}$} \\
\hline & 0 & 2 & 4 & 6 & 8 & & & \\
\hline \multicolumn{9}{|c|}{ 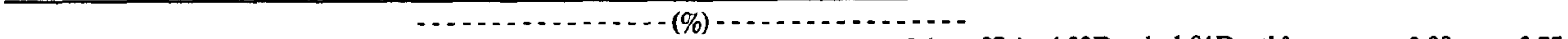 } \\
\hline Dahurian wildrye & 100 & 95.3 & 86.3 & 68.7 & 17.6 & 97.4+ 4.92Depth-1.81Depth2 & 0.98 & 3.77 \\
\hline Russian wildrye-tetraploid & 100 & 93.1 & 75.5 & 48.3 & 21.3 & 101.0- 3.01Depth-0.89Depth ${ }^{2}$ & 0.98 & 1.09 \\
\hline Russian wildrye-diploid & 100 & 73.6 & 47.4 & 10.2 & 0.3 & 98.9-13.14Depth & 0.98 & 1.09 \\
\hline Altai wildrye & 100 & 85.1 & 66.9 & 63.9 & 48.7 & 97.7- 6.19Depth & 0.97 & 0.67 \\
\hline Intermediate Wheatgrass & 100 & 64.5 & 45.0 & 27.6 & 12.7 & 98.4-16.73Depth+0.77Depth2 & 0.99 & 1.82 \\
\hline Crested Wheatgrass & 100 & 76.1 & 25.5 & 2.8 & 0.6 & 105.6-23.79Depth+1.27Depth ${ }^{2}$ & 0.96 & 6.56 \\
\hline Slender Wheatgrass & 100 & 91.4 & 64.4 & 36.4 & 15.7 & 106.3-11.18Depth & 0.98 & 0.98 \\
\hline Nutall's Alkaligrass & 100 & 13.2 & 0 & 0 & 0 & 92.0-37.34Depth+3.33Depth2 & 0.92 & 9.44 \\
\hline
\end{tabular}

ISEE = Standard error of estimate for first order regression coefficient. 
Russian wildrye. The higher seedling vigor (Lawrence et al. 1990b) of this species and its better emergence from deep seed placement than current dryland grasses are agronomic advantages for seeding on semiarid rangelands. The very low emergence of Nuttall's alkali grass from $2 \mathrm{~cm}$ depth indicates that if this species is used in reclaiming wet saline soil seeps, broadcast seeding will be required.

\section{Literature Cited}

Kilcher, M.R., and T. Lawrence. 1970. Emergence of Altai wild ryegrass and other grasses as influenced by depth of seeding and soil type. Can. J. Plant Sci. 50:475-479.
Lawrence, T. 1979. Swift, Russian wild ryegrass. Can. J. Plant Sci. 59:515-518.

Lawrence, T., and F.B. Dyck. 1990. A comparison of two furrow openerdepth control assemblies for seeding forage grasses. J. Range Manage. 43:82-83.

Lawrence, T., P.G. Jefferson, and C.D. Ratzlaff. 1990a. James and Arthur, two cultivars of Dahurian wild ryegrass. Can. J. Plant Sci. 70:1 187-1190. Lawrence, T., and C.D. Ratzlaff. 1985. Evaluation of fourteen grass populations as forage crops for southwestern Saskatchewan. Can. J. Plant Sci. 65;951-957.

Lawrence, T., A.E. Slinkard, C.D. Ratzlaff, N.W. Holt, and P.G. Jefferson. 1990b. Tetracan, Russian wild ryegrass. Can. J. Plant Sci. 70:311-313. 